\title{
K PROSTUPOVÁNÍ ŽIDOVSKÝCH A KŘESŤANSKÝCH ELEMENTŮ V DÍLE VOJTĚCHA RAKOUSE A ELIZY ORZESZKOVÉ: POZNÁMKY K „CENTRIZMU“ A „EXKLUZIVITĚ" ZOBRAZOVANÉHO PROSTORU
}

\author{
ALEXEJ MIKULÁŠEK
}

Mikulášek, Alexej: The Interconnection of Jewish and Christian Motifs in Literary Works by Vojtěch Rakous and Eliza Orzeszková: Notes to "Centrism" and "Exclusivity" of Depicted Space, 2019, Vol. 1, Issue 2, pp. 45 - 55. DOI: 10.17846/CEV.2019.01.2.45-55.

\begin{abstract}
The following study deals with the permeation and interaction of Jewish ani Christian elements, or the barrier and hedge between them, in the collection of stories Modche a Rezi written by Vojtěch Rakous (1862 - 1935) and in the novel Meir Ezofowicz, created in 1878 by a famous Polish writer Eliza Orzeszkowa (1841 - 1910). Modche a Rezi was the most celebrated cycle of Rakous's works and brought a lot of humoristic and comic, mainly situation images. Orzeszkowa's novel brings first and foremost tragical images from the Polish-Belorussian-Lithuanian ghetto named Šibov.
\end{abstract}

KEYWORDS: Vojtěch Rakous. Eliza Orzeszkowa. Modche a Rezi. Meir Ezofowicz. Jews and Christians.

Analýza cyklu povídek Modche a Rezi, díla českožidovského spisovatele Vojtěcha Rakouse (1862 - 1935), na niž se budeme v tomto př́spěvku odvolávat (Mikulášek 2018) ukázala řadu podob prostupování, ba téměř splývání českých a židovských motivů. Dochází k interferenci českých křestanských a českých židovských elementů v zobrazení konkrétního areálu, v Rakousových povídkách a črtách areálu středočeského; to se autorovi stává zdrojem komiky, situační i slovní komiky, zdrojem jemné nadsázky a ironie. Jako protiklad, v kontrastivní perspektivě, se jeví jednající postavy, jazyk, gestace vypravěče i zobrazený areál románu polské „pozitivistické“ spisovatelky Elizy Orzeszkové (1841 - 1910) nazvaného Meir Ezofowicz (v českém překladu s počeštěným pravopisem jako „Meir Ezofovič “1). Autorkou zachycený a časově ne zcela ukotvený prostor, ovšem pouze podle názvu fiktivní „židovské město Šibov“ “2 jeví se jako „čistý“ protiklad „inkluzivního“

1 Román byl poprvé publikován v roce 1878. Do češtiny byl přeložen Františkem Aloisem Horou (šlo o první autorčino dílo $\mathrm{v}$ českém překladu) a vydán o čtyři roky později $\mathrm{v}$ roce 1882 pod počeštěnou podobou jména ústřední postavy Meir Ezofovič a s ilustracemi Elvira Michała Andriolliho (v nakladatelství Aloise Hynka). Nesl podtitul Román ze života polských židưv. Patrně ve stejném roce se objevil (nedatovaný) př̀klad Vácslava Poka (Praha: Karel Bellmann, 330 s.) identického názvu, ale s podtitulem povídka ze života židiov běloruských. $\mathrm{V}$ této studii citujeme $\mathrm{z}$ modernějšího a slovesně barvitějšího překladu Františka Hřivny (Praha: Mladá fronta, 1953, 317 s., s doslovem T. Silbernáglové), knihy vydané opět pod částečně počeštěným názvem Meir Ezofovič. Připomeňme současně, že citovaný román byl vydán $\mathrm{v}$ době politických procesů s antisemitským podtextem, aniž by svým charakterem tento podtext jakkoli podporoval - spíše naopak. „Daní době“ ovšem zůstává mj. fakt, že nebyla publikována autorčina nábožensky tolerantní dedikace, kterou citujeme z polské edice, ani část Úvodu, kterou též citujeme z polského elektronického vydání, je kritická a je doprovázená podrobným poznámkovým aparátem, poznámkami autorčinými i editorskými. Český překlad tedy citujeme v podobě „Orzeszková 1953, XY“, polskou edici v podobě „Meir Ezofowicz, XY“.

2 „Szybów? Na jakiej planecie znajduje się miejsce to? A jeżeli na naszej, jaka je zamieszkuje ludność, $z$ białych, czarnych czy brązowych ludzi złożona? Otóż, czytelnicy, podejmuję się zaznajomić was $z$ ta głęboką, bardzo głęboką doliną społeczną, która nosi tylko co wymienioną nazwę. Niedawno odegrał się $w$ niej dramat ciekawy, godzien życzliwego spojrzenia waszego, silnego uderzenia serca i dtugiej, smętnej chwili zadumy. Że jednak dla pełnego uwydatnienia faktów i postaci należy ukazać je na tle, śród którego 
světa české vesnice, v níž židé nepředstavují „cizí element“, nějaké „neznámé orientální mystické prostředí, cizí svérázný svět “3. Jak jsme si ukázali jinde (Mikulášek 2018), Rakousovi židovské postavy jsou v mnohém Češi, kteří ovšem spatřují svoji židovskou identitu v židovské rodinné tradici, $\mathrm{v}$ původu a vyznání, $\mathrm{v}$ kulturních a náboženských tradicích a rituálech, přičemž humoristická česko-židovská perspektiva vrhá dvojí světlo - jednak na českou majoritu, která vyhlíží $\mathrm{v}$ „židovském světle“ velmi málo „árijsky uvědoměle“ (kdybychom si měli pomoci termínem nacistické propagandy), jednak na židovskou minoritu, které v českém světle ztrácí stopy „cizosti“ a „nepatřičnosti“: přičemž obě kultury k sobě mají tak blízko, že téměř splývají, jakkoli si židovskou identitu a kulturní zázemí ponechávají jako „dědictvi““.

$\mathrm{V}$ naší studii budeme pozornost věnovat především dílu polské spisovatelky ${ }^{4}$, jen $\mathrm{v}$ komparacích připomeneme již publikované závěry ze studií o cyklu Modche a Rezi Vojtěcha Rakousa, popř. připojíme další české paralely. Pokusíme se prokázat, nebo naopak zpochybnit, hypotézu, podle níž je spisovatelkou portrétovaný „židovský svět“ uzavřen v hranicích ghetta a je tedy cele a výlučně, nebo alespoň především „exkluzivní, a to jazykem, kulturou, rituály, kolektivní mentalitou etc.

Autorka své dílo věnovala v dobré víře všem „ziomkom moim“ toužícím po světle, míru a pokoji, nehledě na to, kde a jakým způsobem „oddaja oni cześć Bogu“ (Meir Ezofowicz, 3). V autorčině perspektivě existuje tedy cosi neklamně inkluzivního, sjednocujícího, budujícího mosty nad rozpory náboženskými i jinými ${ }^{5}$ - kdybychom mohli parafrázovat, tedy že „my“ lidé „máme“ jednoho Boha a je lhostejno, jak mu vzdáváme poctu, jak jej velebíme... Tento př́stup podtrhuje nejen dedikace, obracející se ke „krajanům“, ale i autorčina předmluva, v níž je lidstvo chápáno jako široký kmen o mnoha a mnoha větvích, přičemž je to právě osvěta, která „nejlepším jest apoštolem všeobecného bratrstvi i" ${ }^{6}$ Už od prvních vět je zřejmý humanisticko-osvícenský (a v tomto duchu

powstały one i rozwinęły się i w którego głębokich perspektywach mieszczą się ży wioły będące przyczyną ich bytu, pozwólcie, abym przed odsłonięciem zasłony ukrywającej pierwsze sceny dramatu opowiedziała wam w krótkich rysach zawartą historie malego masteczka” (Meir Ezofowicz, 3).

3 Takto hodnotí poměr „katolických obyvatel Polska k polským židům“ Terezie Silbernáglová, autorka doslovu k citované edici (315).

4 Román volíme už s ohledem na jeho rezonanci v českém prostředí, o čemž mj. svědčí dva různé překlady prakticky v témž roce (1882). Jak upozorňuje polský badatel W. Panas, objevuje se v polské literatuře let 1850 - 1900 mnoho děl, která ve svém názvu obsahují nejen slova jako Žid, Izrael nebo Izraelita, ale také slova a jména židovská: „C. K. Norwid, Żydowie polscy (1861); M. Romanowski, Rabin (1862); J. I. Kraszewski, Żyd (1866); E. Lubowski, Żyd (1869); A. Asnyk, Żyd (1875); M. Bałucki, Żydówka (1870); W. Feldman, Żydziak (1889); T. Lenartowicz, Izrael (1865); W. Przyborowski, Hinda (1869); E. Orzeszkowa, Eli Makower (1875); Meir Ezofowicz (1878); A. Świętochowski, Chawa Rubin (1879); A. Szymański, Srul z Lubartowa (1885); J. Łętowski, Josek Gesundheit i Spółka (1886); M. Konopnicka, Mendel Gdański (1890); K. Junosza-Szaniawski, Froim (1899); I. Maciejowski-Sewer, Zyzma (1896); G. Zapolska, Małka Szwarcenkopf (1897), Jojne Firułkes (1898); W. Gomulicki, El mole rachmim (1886)“ (Panas, 1996, 5). Připomeňme současně, že podle Slovníku polských spisovatelů (Ludvík Štěpán a kol., Praha, 2000) bylo „jen mezi 80. lety 19. století a 20. lety 20. století publikováno na dvacet překladů autorčiných děl do češtiny (376).

5 V roce 1953 vyšla i monografie Karla Krejčího Dějiny polské literatury, v níž je dobovým lexikem hodnocen přínos románu: „Spojené úsilí pokrokových židů s pokrokovými křestany proti úzkoprsé zaostalosti, náboženskému formalismu, ubíjejícímu tradicionalismu i nesnášenlivosti náboženské, národní i rasové, je vedoucí myšlenkou románu, vynikajícího barvitým líčením zpola exotického prostředí i poesií, vloženou do mírně idealisovaných postav několika sympatických lidí, hlavně titulního hrdiny“ (374).

${ }^{6}$ „U szczytów cywilizacji zbiegają się i zgodnie łączą się ze sobą różnorodne gałęzie wielkiego drzewa ludzkości. Oświata najlepszym jest apostołem powszechnego braterstwa. Wygładza ona chropowatości zewnętrzne i ścina wewnętrzne wybujałości, dozwala przyrodzonym cechom plemion różnych rozwijać się 
i tendenční v nepejorativním smyslu slova) postoj autorčin: lidstvo je jedno, lidství jest nejvyšší hodnotou, poznání pak „světlem“ ukazujícím cestu, sjednocujícím a předsudky bortícím.

Židovské postavy románu polské spisovatelky jsou především, ba výlučně Židé silně ovlivňovaní realitou i mentalitou ghetta. $V$ autorčině perspektivě až fatálně podléhají učení právě těch rabínů, již se cítí být výlučnými „služebníky Hospodinovými“, částečně v duchu kabalistického a chasidského učení, autoritativními strážci výlučné Hospodinovy vưle. Tento prostor je pak vyhraněně „exkluzivní, uzavřený, v autorčině perspektivě reprezentován až uhrančivým vlivem rabínského rodu Todrosů, ohraničený zdmi ortodoxního židovského ghetta, polsko-bělorusko-litevského Šibova (jeho historii na úvod autorka dopodrobna popisuje, využívajíc některých postupů románové kroniky). Do „městečka“ myšlenky umírněného rabinismu, reprezentované podnikatelským rodem Ezofovičů, myšlenky židovsky osvícenské, vstoupit nemohou, resp. jsou vytěsňovány jako cosi cizího, ba nepřátelského. Jestliže česká židovská žena všemi oslovována familiárním výrazem, jež je ekvivalentem k Tereze či Terezii, tedy jako „Rezi“, vlastním jménem však „Rive/Rifke“(ale jako Rezi ji oslovoval „celý svět“) (Rakous 1992, 4) z Rakousových povídek nevidí nic neobvyklého na tom, že připravuje macesy ${ }^{7}$ společně s komunitou svých nežidovských sousedů (dokonce od ní každý dostane jeden maces „coby výslužku“), byla by podobná „rouhavá“ činnost v „todrosovském“ Šibově nemyslitelná, doprovázená okázalým a téměř všeobecným pohrdáním, jistě odsudkem. Oba prostory se však nejen v tomto punktu jeví jako mimoběžné.

Centrismus $^{8}$ ghetta je podstatně silnější než tendence, jež ghetto přesahují. A navíc ani existenci postav „transcendujících“ tento prostor nelze (v autorčině perspektivě) hodnotit vždy a jednoznačně pozitivně. To je patrné už na charakteristikách těch židů, kteří přijíždějí do Šibova „Z města“, z moderního velkoměsta, a jsou zaraženi a otřeseni civilizační úrovní šibovských obyvatel. Zobrazený prostor se jim jeví jako prostoupený fanatismem. Sami však jen obtížně skrývají povrchnost a prízemnost, lpí jen na vnějších symbolech civilizace a reformátorovi Meiru Ezofoviči jsou cizí jako bytosti „bez duše a ducha“. Na ně se nelze spoléhat... Takovými jsou např. manželka Eliho Vitebského Hana, která vzbudila „nedobrý dojem u ultrakonservativních obyvatel zapadlého kouta“ (Orzeszková 1953, 124), jež „byla zamilována do civilizace, která se jí prèstavovala $v$ podobě krásných šatů, vlastních vlasů na hlavě, pěkně zařizených pokojů, velmi zdvořilého obcování s lidmi, francouzského jazyka a hudby“ (ibid., 126). Její vztah k judaismu se vyčerpává vírou v „pověry“, $\mathrm{z}$ nichž rovněž podezírá obyvatele Šibova, tedy „věrila i $v$ dábly a bála se jich ještě více než Pána Boha“. Její rituály jsou vykonávány mechanicky, dokonce si v duchu myslela, že „by

obok siebie we wzajemnym poszanowaniu, same nawet religijne wierzenia oczyszcza z narośli wytworzonych przez zmienne czasy, a sprowadzając je do najprostszego ich wyrazu, sprawia, iż spotykaja się one ze soba bez wstrętów i szkód" (Meif Ezofowicz, 3).

$7 \quad$ Text z Modche a Rezi citujeme podle edice z roku 1992, tedy Rakous, Vojtěch: Modche a Rezi. Praha: Petrklíč, 1992. ISBN 80-852 43-29-6. Vydání obsahuje rovněž výbor z povídek cyklů Kieslerův Lojza, Dědeček a babička, Židé a židovky a Doma. Editor není uveden.

8 Pojem „centrismus“ je užíván s adjektivem literární v komparatistice, kde navazuje na podněty Dionýze Ďurišina a jeho týmu („literárne centrizmy“). My tímto pojmem míníme uzavřenou soustřednost, která je protikladem transgrese, otevřenosti, sociálního i duchovního přesahu. Centrický prostor je exkluzivní, s vlastní ideologií, hodnotami, mentalitou, symboly, jazykem a rituály, s autoritami nevstř́cnými vůči čemukoli „cizímu“. Transcentrismus je naopak inkluzivní a sám inkluzivitu předpokládá, integruje domněle cizorodé prvky, k nimž je tolerantní, předpokládá však existenci společné báze, na níž „cizi“ přestává být „cizím a stává se „naším“. Touto společnou bází může být vědomí př́íslušnosti k multietnickému prostoru, „společné vlasti“, společný jazyk, společné „člověčenství (v případě autorského hlediska Elizy Orzeszkové) etc. Ze spaciálního hlediska jsou Rakousovy povídky př́kladem prostoru transcentrického, přesahujícího, inkluzivního, tolerantního, resp. přátelského k „cizím elementům“, at” už je „cizím elementem“ míněna etnicko-náboženská majorita nebo minorita, křestané nebo židé. 
bylo daleko lépe, kdyby Židé jedli totéž maso jako křestané, nebot' by jim př̌ǐlo daleko levněji“ (ibid., 127). Podobné „krevní skupiny“ jsou i její dcera Mera a „mladý sestřenec paní Hany Leopold“ (ibid., 129). I Hana chce imponovat, předvádět se „oděvem, nábytkem, chováním, výslovnosti“ (ibid., 127). A to na rozdíl od jejího sice v lecčem „moderního“, ale mimořádně inteligentního manžela, jenž si všechny získává svojí př́ivětivostí, srdečností a obratností, vcelku liberála, jenž se cítil „spokojený a štastný (...) a bylo mu úplně a upřímně lhostejno, zda člověk, s kterým měl co dělat, byl talmudista, kabalista, chasid, pravověrný, odpadlík nebo dokonce edomita, jen když mu osobně neškodil“ (ibid., 125).

Ambivalentní postoj autorského vypravěče se v poetice románu (nejen tedy v pojetí prostoru) projevuje na mnoha místech. Tento explicitně dává najevo, že duchovní patos ghetta, onu exkluzivitu a centrismus jeho todroských rabínů v jistém smyslu obdivuje, protože má své tajemství a romantiku, poezii, cosi duchovně krásného a mystického, obdivovaného Martinem Buberem v Chasidských vyprávěních nebo Jiřím/Georgem Langerem v Devíti branách (vydaných s podtitulem „Chasidů tajemstvi“). Jde přece o svět chudých, „a přece tak bohatých duchư!“ (ibid., 145). Poezie „kabaly“ s její symbolikou a s andělsky pohádkovými bytostmi je v románu bohatě a bohatě využita. Kázání a učené rozpravy, četná rozjímání stejně jako „vidění šibovského rabína (a jeho učedníků) mají také nespornou literárně estetickou hodnotu. Jistě je v textu a jeho stylu využito i učení talmudických rabínů, dokonce i vět temných v současném smyslu slova, srov. „Bud’blahoslaven Bože, Pane světa, za to, že jsi mne nestvořil pohanem, bud' blahoslaven za to, že jsi mne nestvořil nevolníkem! Blahoslaven bud, že jsi mne nestvořil ženou!“" (ibid., 177).9

Děj je zasazen do „běloruské končiny“, daleko „od splavné ř reky Dviny“ (ibid., 5), děje se „v jednom z nejodlehlejších zákoutí, jaká ještě mohou být v Evropě (ibid.). Jádro zachyceného příběhu, konflikt Meira Ezofoviče s rabínskou autoritou a mentalitou ghetta, není časově určen, dủležitá je snad formulace, že se odehrál „nedávno“. S výrazným slovesným a současně výtvarným talentem je portrétován Šibov jako židovské městečko, „městečko obývané židovským obyvatelstvem ještě výlučněji než mnoho jiných podobných městeček“, zde „šedá se skupina několika set větších i menších domů tak blízko $k$ sobě pritisknutých, že bys při pohledu na ně řekl, že se tak k sobě kdysi sběhly $z$ velkého strachu, aby si mohly v těsném sousedství vyměňovat šepoty a slzy“ (ibid., 5). Toliko jedna ulička „na samém okraji městečka“ byla obývána skupinou „velmi chudých měštanů a velmi tichých starých penzistü“, což dává tušit rovněž existenci minority ,jinověrcü“, patrně křest̉anů. Jen zde "panuje ticho a v létě kvetou skrovné květy“ (ibid.). Bylo to místo, „v němž se soustředují a jež představuje světské i náboženské autority“ (ibid., 7) celého regionu.

Oba texty, Rakousův i Orszeszkowé, vplývají do proudu široce chápaného realismu, v polské tradici nazývaného „pozitivismus“, o čemž svědčí už plastické, motivicky názorné, dojem přesvědčivosti a reálnosti vzbuzující předmětné detaily i široká panoramata, popisně detailní pasáže (samozřejmě s přihlédnutím ke specifikům žánru - na jedné straně krátké humoristické povídky, na druhé straně románu s výraznou osvětovou tendencí). V obou hraje důležitou roli prostor (prostorovost, spaciálnost), jehož poznáním oba spisovatelé podmiňují pochopení činů svých postav (odtud i dlouhý deskriptivní historický úvod Meira Ezofoviče). Rakousovy povídky jsou neodmyslitelné od reality české (středočeské) vesnice, $v$ níž jsou židé namnoze (či částečně) zcela integrovanou, výjimečně i plně asimilovanou (stvrzenou i náboženskou konverzí k většinové společnosti) minoritou, vlastně splývají s majoritní společností českou a jen antisemitismus by jim připomínal jejich židovství, resp. původ (z něhož „nelze vystoupit“ jako z židovské obce).

\footnotetext{
V monografii Tanu rabanan mají tři modlitby, připisované Rabi Jehudovi, resp. „požehnání, jež je člověk „povinen pronést denně, tuto podobu: „Požehnán bud”, že jsi mě neučinil gojem. Požehnán bud, že jsi mě neučinil buranem. Požehnán bud”, že jsi mě neučinil ženou“ (Sláma 2010, 263). Pro antisemity byla tato slova důkazem „záhubného působení židovstva“ a široce propagandisticky zneužívána.
} 
Provázanost je typickým prvkem tohoto vesnického společenství a společně sdíleného areálu. Existence odloučeného a „vyloučeného“ Šibova by byla v podmínkách středočeské vesnice (v prostoru zachycovaném Vojtěchem Rakousem) absurdní, dokonce i pražské Židovské Město před asanací nebylo obýváno téměř výlučně „pravověrnými“ židy/Židy a nepanovaly v něm téměř stř̌edověké poměry: bylo spíše sociálním než nábožensko-etnickým ghettem a heslo „pryč z ghetta" stalo se heslem nejen českých židů od dob první (Josefem II. vyhlášené) emancipace. Zato zástupy židů z „Bílé Rusi“ a Litvy „věřily, uctívaly a hrnuly se do Šibova jako do místa Svatého, s poklonami, pro naučení, radu, útěchu a léky“ (ibid., 8). Bylo jim vzorem a archou „náboženské pravověrnosti“, o níž ovšem někteří „učení talmudiste“ neveřejně pochybovali a „cosi o ní smutně šeptali“ (ibid.). Jak uvádí „vševědouci“" autorčin vypravěč na jiném místě, značná „část obyvatelstva byla vlastně chasidská, aniž o tom věděla" (ibid, 85). Už Úvod románu tak dává tušit, že oba vypravěči, Rakousův i Orzeszkové, budou své postavy nejen podrobně portrétovat, že je „ukotvi“ konkrétním prostorem, ale že je budou i hodnotit, samozřejmě každý s jinou tendencí - Rakous jistě s humoristickou nadsázkou, $\mathrm{v}$ „konečné instanci“ se zábavnou funkcí, Orzeszková s široce dokumentárním a osvětovým, „tendenčním“ záměrem působit na židovskou i nežidovskou komunitu ve smyslu ideálů tolerance a humanismu.

Jakkoli jsou oba autoři jiného náboženského vyznání, jiného původu, jazyka a pohlaví, jiné národnosti etc., mají mnoho společného, a to nejen skutečnost, že V. Rakous je tolerantní „mosaista“ a E. Orzeszková tolerantní křestanka. Především oba vidí integraci židů/Židů do „inkluzivního“ prostoru jako reálné řešení „židovské otázky“ - jakkoli tento výraz nepoužívají. I přes zásadní odlišnost tematickou, danou na straně jedné provázaností všech „obyvatel české vesnice“ (židů i křestanů), a „odloučenectvím“ židů v („dobrovolném“) ghettu na straně druhé, je oběma autorům vlastní humanismus jako hlavní hodnota stojící nade všemi vyznáními a rituály, smysl pro skutečnost a „zdravý rozum“, přirozené hodnoty lidského života. S tím je „přirozeně“ spjat odpor k iracionálním, jakkoli mystickým a působivým „pověrám“ a k jakémukoli „přepínáni“" náboženské duchovní víry, jež „zatemňuje mozek“ a vede k fanatismu. Oba se obracejí zdaleka nikoli jen k židovskému publiku, ale i ke křestanům s cílem „ukázat“ jim hodnoty, jež jimi vytvořené postavy vyznávají jako hodnoty univerzálně lidské. Oba volí lexikální prvky jidiš, které nežidovským čtenářủm určitým způsobem vysvětluji ${ }^{10}$. Projektovaný adresát je vypravěčem oslovován už př́klady a př́měry z křestanského světa; jako takovou lze vnímat charakteristiku „její hnědá, opálená tvár zbledla na okamžik jako hostie“ (ibid., 119). Rovněž čtenář českého překladu uslyší bohaté inverze vlastní humanistické „biblické“ češtině, vytuší její tendenci shodné přívlastky postponovat a slovesa klást na konec vět v periodě, srov. „Nad břehy Babylonu seděli plačíce a vítr sténal v loutnách jejich, kteréž sobě z vlasti přinesli a v zármutku na stromy zavěsili“ (ibid., 121).

Jak už bylo uvedeno výše, Rakous portrétuje českou vesnici (Vojkovice, Sedletín ad.) jako prostor přirozeně inkluzivní, v němž stupeň integrace dosahuje téměř ideálních podob spolupatřičnosti. Krátké povídky nesou četné rysy humoristické idyly, přičemž samotný žánr „idyly“ byl v české literatuře zvláště devatenáctého století naplněn „povídkami“a a obrazy“ Boženy Němcové (Pan učitel, Dobrý člověk), Karla Václava Raise (Zapadlí vlastenci) nebo Jindřicha Šimona Baara (Jan Cimbura, Holoubek). Jakkoli se židovské postavy cítí být Čechy, cítí se současně být i židy (nikoli však Židy v nacionálním smyslu slova), nepostrádají specifičnost danou už praktikovaným náboženským vyznáním a s ním spjatými rituály. Jejich prostorová blízkost křestanskému prvku, sousedské soužití a spolužití je důležitým integračním faktorem. Je jím taktéž jazyk, který je českému i židovskému etniku společný, dokonce mají společný výraz pro modlitebnu, a tím je „kostel“

10 Jak uvádí Štěpán Balík, pracuje Rakous s těmito lexikálními elementy s ohledem na českého (českojazyčného) čtenáře a záměrně omezuje jejich počet volbou českých ekvivalentů (Balík 2015, 67). Eliza Orzeszkowa „čtenáři-krajanovi“ méně známá fakta a výrazy vysvětluje v autorských poznámkách. 
(tu křestanský..., tam židovský...). Rakous je vynikající vypravěč, v jehož povídkách se stále něco „děje“ a jisté dějové napětí je důležitou složkou fabulační výstavby textu, slova jidiš původu jsou využita s charakterizační funkcí jen místy a funkčně (Mikulášek 2018).

Eliza Orzeszková takovýto prostor portrétovat nemůže, ale o spolupráci obou etnik sní, pokládá ji za prospěšnou pro „obě strany“. Velmi kriticky její vypravěč hledí na učení, jež proklamuje „hluboký, nezlomný odpor k edomitům, cizím národi̊m, a k jejich vědě (Orzeszková 1953, 85). Láká ji tajemství a metafyzická duchovnost, cizí jí zůstává „tajemná prísnost a neodpouštějicí nenávist ke všemu, co žilo, toužilo, věrilo jinak než on“, tj. rabi Izák Todros (ibid., 86). Tolerance, vzájemné poznání a o fakta opřené vědění, spolupráce mezi národy, to jsou naopak hodnoty, jež vévodí protilehlému židovskému světu, reprezentovanému rodem Ezofovičů. Jimi vlastněný „poklad“ jako učení tolerance také získává sympatie autorského vypravěče a představuje naději pro celou šibovskou komunitu.

Jestliže povídky mají výrazně dějový ráz a těží - vedle jazykové komiky - nejednou ze situačních scén, přičemž se oba hlavní aktéři jeví jako reliéfní figurky (Modche nepraktický, „pod pantoflem“, lehce ovlivnitelný, Rezi naopak panovačná, praktická a zásadová), potom román zdůrazňuje spaciálnost četnými poetickými deskripcemi. V analyzovaném románě hrají velmi důležitou roli metaforická líčení, barvitá, prostř̌ednictvím střídání „scén“ a scenérie se pohybuje děj románu vpřed. Jeho vypravěč se zaměřuje na četné vizuální efekty jako na dominanty své plastické prostorové deskripce, srov. jen toto zrcadlení: „Měsíc osvětloval obě tváre těchto lidí, z nichž jeden se díval na nebesa a druhý na tvár svého mistra. Mistr planoucím zrakem hledal na nebi světelné čmouhy, které označují cestu andělů vedoucích hvězdy na jejich věčné pouti prostorem, učedník hledal v zřitelnicích svého mistra odrazy oněch nadprirozených světel“ (ibid., 295). Tato scéna "planoucích zrakü“ a odlesků „nadpřirozených světel“ v očích rabínových a učedníkových připomene černobílou filmovou sekvenci. Světelné efekty jsou doprovázeny barvami a kontrasty, srov. scénu začínající tím, že se otevřely „dveře sousední jizby a v zlatém osvětlení ohniště, jež tam široce plálo, objevila se na prahu mladá, štíhlá žena. Měla na hlavě veliký bilý turban, bílá zástěra spadala jí od šíje ozdobené několika šňưrami perel až k lemu květované sukně. Ohromné černé oči jí svítily vesele a ohnivě v poutavé, milé tváŕi “ (ibid., 19, zvýraznil autor př́íspěvku). Zlatá, červená, bílá, černá i „květovaná“ barva konkretizují prostor, zaplňují jej, utvářejí prostorové dominanty. Tyto vizuální efekty, barvy a jejich kombinace nejsou jen prostředkem popisu prostředí a postav a fabulačním prostředkem výstavby, ale mají i psychologickou a symbolickou funkci. Oko se stává zrcadlem toho, na co pohlédlo, je samo pohledem do nitra člověka. Mimořádnou působivost románu spatřujeme právě v jeho poetice ${ }^{11}$, zatímco „ideový plán“ trpí jistou proklamativností a vypjatou rétoričností, kterou najdeme především v pasážích zprostředkovávajících náboženské spory nebo persuasivní strategii vypravěče velmi blízkého autorce. Ten má dozajista panoramatický přehled o postavách, namnoze ví více než ony samy. Je „stranický“ a hodnotící; např. o rabbim Izáku Todrosovi píše, že „byl by býval zcela jistě velkým člověkem, kdyby nikdy nebylo těch, kteři použivajíce ohně, mučení a ještě stokrát horšiho

11 Polský badatel W. Panas hodnotí autorčinu poetiku rovněž velmi vysoko, podobně jako W. Zavodziński: „Użyte w powieści środki artystyczne, zwłaszcza w zakresie warstwy językowej, zblizają jej utwór do poezji. Liczne elementy języka poetyckiego: rytmizacja, stylizacja, organizacja eufonologiczna, obrazowanie osłabiaja „epickość” i wzmacniaja „żywioł liryczny”. Orzeszkowa napisała poemat religijny. Poetyckość jest tym środkiem, który pozwala przełamać ograniczenia, stanowi medium przenoszace $w$ sferę sacrum. Lecz przecież ów "poemat” pozostaje $w$ granicach powieści, rodząc $w$ ten sposób wewnętrzne napięcie $i$ ambiwalencję. "Romans", „poemat”: formy wypowiedzi, która ma za przedmiot doświadczenie transgresywne. Bo też świat, o którym chce opowiadać jawi się - temu, kto opowiada - jako fenomen dwoistości. A świętość prześwituje w szczelinach formowanych przez poezję. Metafora staje się metafizyka”" (Panas 1996, 11). 
než to - pohrdání, postavili pokolením jeho plemene až do daleké, daleké budoucnosti ghetto morální a duševní, těsné a temné, plné strachu a odporu“ (ibid., 264).

Vojtěch Rakous píše z aktuální perspektivy a životní zkušenosti, dávnou minulostí svých postav se v podstatě nezabývá (exkurze do minulosti rodu Korefů a Kantůrků jsou výjimečné, důležitá je v jeho povídkách především jejich současná „přirozená“ česká existence a její perspektivy v budoucnosti, zvláště ekonomické zázemí etc.). Orzeszková nás naopak seznamuje i s dávnou i pradávnou historií svých postav a rodů, místy čteme cosi jako kroniku rodu a města, jehož zakladatelé byli „karaité“, respektive „odštěpenci, kteří predstavovali v židovstvu zkoumavého ducha opozice“ (ibid., 8), také kdysi, „je tomu dávno, obrátili na svou víru obyvatele vínem a zlatem oplývající země chersonské a stali se jejími králi“, později se vydali „na pout’ světem, dvojnásobní vyhnanci Palestiny a Krymu“, malá část se dostala „až na Bílou Rus a tam se usadila v hromádce domků a lepenic, kterou nazvali Šibovem“ (ibid., 8). Vedle „karaitů“ začíná přibývat těch talmudistů, kteří začínají „pravověrné“ vytěsňovat jako heretiky, „karaitská obec pomalu tála“ (ibid., 9). Vypravěč cituje i text diplomu, jímž král Zikmund I. „Michala Ezofoviče seniora“ jmenoval čímsi jako svým tajemníkem ${ }^{12}$. Už v Úvodu k románu se jeho jméno „vynořilo ze stínu neznáma“. Jeho rodinu, která byla „usedlá v Polsku od pradávna“, což jest motiv blízký Rakousovi, motiv kontinuitní existence židovského prvku a jeho př́tomnost v areálu, už za vlády Jagellonců „vlivem práv a obyčejů vytvořených na ony časy neobvykle vysokou úrovní osvěty v Polsku spojily přátelské svazky s místním obyvatelstvem“ (ibid., 9). Vedle kontinuity je důležitý jednak motiv osvěty (vědění, poznání, humanistického rozhledu), jednak motiv vůle a citu, onen „přátelský vztah“ k majoritě, $\mathrm{k}$ „místnímu obyvatelstvu.

Tyto tři motivy, tedy kontinuitní př́íslušnost $\mathrm{k}$ areálu, osvěta a vzdělanost, konečně i přátelské kontakty s majoritou, budou významné i pro interpretaci látky, kterou román rozvíjí, nebot se stávají čímsi, co mentalitu duchovního ghetta „rozleptává“ a jeho obyvatele do jisté míry osvobozuje, a tak „rabbanité“ „svojí pílí, přičinlivostí a těsnou spoluprací, jejiž síla tkvěla v téměř bezpříkladné vzájemné pomoci, změnili temné zapadlé městečko (...) v místo ruchu, hluku, přičinění a bohatstvi" (ibid., 10). Židům tak svitla „naděje na vyproštění z duchovní temnoty a ze společenského poníženi“ (ibid., 10 - 11). Autorský vypravěč chválí „seniora Ezofoviče“ jako „jistě bystrého a jasného ducha“, jenž dovedl „preses staleté předsudky a pověry postřehnout ducha času a potřeby svého lidu“, dokonce „navštěvoval někdy jeho ducha skepticismus, nejlepší a snad jediná cesta k moudrosti“ (ibid., 11). Tyto v zásadě humanistické a osvícenecké ideály však nezvítězily, když „straníci bezpodminečného vyloučení Židi z podílu na duševní práci a lidském snažení predstavovali ohromnou většinu“ (ibid., 11), což vypravěči zřetelně nekonvenuje, ale současně konstatuje, že na „každou společnost přicházejí někdy chvíle takového úpadku do temnot", která pro západní židovstvo nastala v 16. století, kdy bylo rovněž opuštěno dědictví Majmonidovo, onoho obra „s pohledem orlím a srdcem plamenným“ (ibid., 12), jehož vystřídali „trpaslíci s hrudí zmučenou, presycenou hořkostí, se zrakem patřicím na svět kalně, omezeně, podezíravě (ibid.). Došlo k tomu - podle vypravěčových slov, jenž jako by objektivně a věcně „referoval“ o skutečnosti svého zájmu, ale současně ji i př́mo hodnotí, - po příchodu Nehemiáše Todrose, jenž „přišel ze Španělska do Polska a usadil se v Šibově, sice potomek „onoho slavného Todrosa Abulaffi Haleviho“, jenž se ovšem „dal zavést temnými taji kabalistiky (mysticismu)“, takže se přičinil o to, že „v židovstvu vznikl jeden z nejkrutějších omylů, jakému může podlehnout duch národa“ (ibid., 14). ${ }^{13}$ Konflikt mezi kabalistickou mystikou a osvícenským kritickým, přitom však tolerantním myšlením se stane „páteři“ románového tvaru.

12 "Michal Ezofowicz and his descendants are the only examples on record of Polish Jews who achieved noble status without conversion. They are the subject of Eliza Orzeszkowa's novel Meir Ezofowicz" (Teter, Magda, 2017. Ezofowicz Family. In: The Yivo Encyclopedia of Jews in Eastern Europe. Yivo Institute for Jewish.).

13 Antisemité mohou využít/zneužít některých částí textu románu, jež jsou velmi kritické a jsou také 
Osou románu je tedy konflikt dvou principů, dvou protilehlých stanovisek, a to extrémního centrismu, reprezentovaného rodem rabínských Todrosů a jejich vlivným učením, (jakkoli spíše kabalistickým než talmudickým, spiše poeticky mystickým), a zdatnými obchodníky Ezofoviči, již se více otevírají světu a překonávají mentalitu ghetta v duchu moderního humanismu, osvícenství a konečně i pokroku devatenáctého století. Vypravěč románu v duchu generační kroniky uvádí na scénu několik zástupců rodu Ezofovičů. Jednak Ezofoviče-seniora, o němž neopomene zdůraznit, že byl „starým polským usedlikem“ (ibid., 14) a že právě jeho přičiněním byla „židovským synodem, který se tehdy sešel, vydána výzva ke všem polským Židưm“, volající „po světské vědě, po sbratření s ostatním lidstvem v duševní práci a usilováni“ (ibid., 13). Přesto „byl Ezofovič poražen“, a to právě „španělským přistěhovalcem“ Todrosem (ibid., 14). Sice „zemřel v plné síle života“, ale usmýkán intrikami a zlobou (ibid.). Todrosové sice „chudí, téměř nuzáci obývající mizernou chatku (...) pohrdali vším, co mělo zdání vkusu, krásy a třebas pohodli“ (ibid., 15). Druhým představitelem Todrosům protikladného rodu byl Herš Ezofovič, „bohatý kupec“ (ibid.), jehož osud je sledován s událostí, jež se stala „na konci minulého stoletî (ibid., tedy ve století osmnáctém), v souvislosti se čtyřletým sněmem, jehož výsledkem byly zásadní reformy, jejichž cílem bylo „odstranit všechny rozdíly, které se vyskytují mezi Židy a mistním obyvatelstvem v odivání, jazyce a zvycích", respektovat náboženské odlišnosti i sekty, „pokud nebudou mít škodlivý vliv na mravy“, a udělit „Židìm právo nabývat půdy" (ibid., 16). A třetí postavou rodu je Heršův pravnuk Meir, skutečně hlavní postava románu, jenž se seznamuje s „pokladem“, zapsaným v pečlivě schovaném rukopise, jehož podstatou je přesvědčení - pro Rakousovy postavy nejde o abstraktní ideál, nýbrž o realitu - že přirozeným prostorem, jakým je i vzduch, který dýchají, není ghetto. S autorčinými ideály rezonující postava Meira se obrací ke svým souvěrcům, že „kdybyste se všichni netísnili tady v těch špinavých, malých uličkách, kdybyste se rozběhli po širém světě a začali pracovat na polích jako křestanští sedláci a nečekali na veliké zisky, možná, že by se vám vedlo na světě líp" (ibid., 168). Jako radikální reformátor $\mathrm{v}$ očích jedněch, heretik v druhých, by rád „mnoho věcí v Izraeli obrátil vzhưru nohama“ (ibid.). Je z rodu neochvějných „hledačů pravdy“, jež v české literatuře exponuje v době realismu snad nejvýrazněji jiná středoevropská realistická prozaička (mj. matka pozdějšího rektora Masarykovy univerzity v Brně, Arna Nováka), tedy Teréza Nováková, nazývajíc svou metodu „dokumentárním realismem“. Meirův hloubavý a hledačský charakter, neúnavná víra v lidskost, jeho četné životní peripetie, do nichž je vtažena i láska k vyloučené „karaistce“ Goldě, až po nucený odchod z Šibova, jsou hlavním tématem románu, v němž nelze nevidět i četné romantické tendence. Jako červená nit se textem románu táhne motiv „pokladu“, rukopisu ukrývaného před nepřejícnými todrosovskými rabíny, slova o nutnosti otevřít se světu a zemi, v níž židé/Židé žijí, vyjít z ghett a čelit výzvám moderní společnosti - je to tentýž „poklad“, který v sobě koncentrují verše česko-židovsko-německého básníka a překladatele Siegfrieda Kappera.

Rakousovy postavy umějí česky stejně dobře jako lidé z jejich okolí, ne-li lépe. Je nemyslitelné, aby žily v ghettech jazykových, jako mnozí obyvatelé Šibova, kteří „nerozumèjí jazyku země, v níž žijí (ibid., 234) a "uměji jen židovsky“ (ibid.). Vypravěč tu zprostředkovává, neprímo „překládá“ řeč pronášenou „židovsky“ do srozumitelné čtenáři. Postavy nežidovské v diegetickém světě však takového zprostředkovatele nemají. A vypravěč postavy i přímo hodnotí jako „ubohé“, nebở ubozí jsou „mudrci izraelští a jejich ctitelé, kteři stíhali nenávistnými pohledy edomitu. Ubohý edomita vysmívající se izraelským mudrcům a jejich ctitelům! Avšak nejbědnější, ach nejbědnější

předmětem kritiky těch židovských postav, jež volají po změně, nebo by ji alespoň přivítaly. Takovým se jeví popis dvou Jankielových dcer a syna Mandela; dcery „dospělé, silné, ošklivé a rozcuchané (...) uklízely trochu s pomocí čtrnáctiletého bratra Mandela, jehož opičí, zlá tváŕ nesla stopy dlouholetých studií v chederu reba Mošeho“(177), přičemž ony „dlouholeté stopy“ jsou narážkou na fyzické útrapy a bití se školou spojené. 
země, jejiž synové po společné, staleté pouti navzájem nerozumějí ani řeči svých úst, ani řeči svých srdcí!“ (ibid., 235 - 236). Jak patrno z těchto rétorických vět pronášených vypravěčem, i zde jsou židé/Židé a Poláci vnímání jako „synové jedné země“, tedy svého druhu bratři, což opět upomene na Siegfrieda Kappera a jeho básnickou sbírku České listy (na jeho reformní, ba radikálně reformní úsilí mezi souvěrci, pojetí Čechů i Židů jako krajanů, synů „země vltavské“, místy připomene i Kapperův artificiální básnickou gestaci i rétorický patos). I jiné postavy mluví jazykem vypravěče a jako on sní o tom, aby lidé, kteří se kdysi nenáviděli a pronásledovali se, „podali si ve shodě ruce“ (ibid., 217). Odloučenost šibovských rabínů však znemožňuje cokoli jiného než pouhou mechanickou kontinuitu s knihami zůstavenými „po dědech a pradědech“ (ibid.). Jazyk těchto promluv je potom stejně patetický jako vypravěče, místy jako kdybychom se stali čtenáři nějaké kazatelské produkce. Na mnoha místech čteme jazyk biblických vyprávění dobře známých i křestanskému čtenáři.

Závěr románu je jistě symbolický a upomene nejen na symbolistickou, ale i na romantickou poetiku. Např. v novele Krysař Viktora Dyka, představitele tzv. anarchistických buřičů a novoromantismu, jest postava Krysaře podobně jako Meira také „vyloučencem“ a vzdoruje autoritě a majoritě, reprezentované zvláště konšely, ale i dalších měštanů hanzovního města Hameln. Zvuku jeho kouzelné pištaly odolává pak jiný vyloučenec, a tím je blázen Sepp Jörgen, a malé dítě, ještě kojenec, oba de facto i z hlediska křestanských evangelií čistí a nevinní - jimž ovšem patří „království nebeské“ („Blahoslavení chudí duchem....”, „Nechte maličkých přistoupiti ke mně..."). Lze tedy pokládat právě za křestanský motiv fakt, že Eliza Orzeszková posílá své dvě postavy také do světa, aby „jdouce jeden za druhým, prokletý mladík i ditě chudáka, zmizeli za pahorkem, kde se pred nimi rozprostřela stopa písčité cesty, vedoucí do širokého a neznámého světa“ (ibid., 312). Ostatně symbolické (křestanské i židovské) prvky prostupují románem na mnoha místech, např̀. symbolický motiv „libanonského cedru“ se poprvé objeví v alegorické „disputaci“, při mezi rebem Nochimem Todrosem, odpůrcem reforem a integrace do polské společnosti, ctitelem př́sného ghetta, a Heršem Ezofovičem, jenž usiluje o povznesení židů, „nejen o hmotné, ale i morální dưstojenství (ibid., 15). Zde se objeví příměr aktuálního postavení Izraele k trní, přičemž obraz cedru libanonského vystupuje jako ideální cíl: bez školy jako základu integrace do většinové společnosti je tento ideál neuskutečnitelný: „Pro naše děti zbudují školy a z Izraele učiní cedr libanonský místo trní “(ibid., 17). A v samotném závěru románu se vyslovuje naděje, jakkoli formou jakési rétorické otázky, tedy zda se hledajícímu podaří najít „zdroj moudrosti“ a přinést Izraeli „ono světlo, jehož mocí se vztyčí cedr libanonský tam, kde se nyní stele nízké trní?“ (ibid., 313). Symbolický motiv „trni““ a „cedru“ se stává jakýmsi svorníkem úvodu i závěru románového tvaru. Ovšem celý román - vedle prvků sentimentálních a romantických - pracuje přímo či nepřímo se symbolickým přesahem, od jmen jako židovská dívka Golda (upomene svým portrétem, ba svojí „kozičkou“ na romantickou, melodramatickou postavu cikánky Esmeraldy z Hugova románu Chrám matky Boží v Pařiži) až po aluze na svět proroků, kteří sice byli Bohem určeni za strážce smlouvy Izraele s povinností slyšet „můj hlas" (Hlas Hospodinův, „Slyšte hlas...") a opakovat „ho lidu svému“ (ibid., 176), kteří byli věrnými služebníky Božími, ale současně jim bylo dáno i trpět, když „Proroku Ezaiašovi ut̉ali hlavu ... proroka Jeremiáše vyhnali z Palestiny (...) Rabi Akiba za svou pravdu zemřel ve velikých mukách“ atd. (ibid., 176). Meir Ezofovič je tak autorským vypravěčem vnímán jako svého druhu „pokračovatel“ této prorocké linie, tedy proroků v něčem připodobňovaných ke „světcům“ a „mučedníkům“, v tomto martyrství ne nepodobně křestanskému mučednictví.

Poslední slova románu jsou přímou deklarací a výzvou čtenáře k toleranci a pomoci bližnímu jakéhokoli vyznání a rasy. Vyzývá jej - „at’ve tvých žilách plyne krev kteréhokoliv plemene a at’vzdáváš poctu svému bohu na kterémkoliv mistě této země - potkáš-li někdy na své cestě Meira Ezofoviče, podej mu upř́mnou, spěšnou a bratrskou dlaň prátelství a pomoci“ (ibid., 313). 
Na závěr můžeme shrnout: obyvatelé „polského“ (běloruského) Šibova jsou z velké části židé tzv. východní, „zbožní a pravověrní" v kabalistickém ukotvení, do něhož jen s obtížemi pronikají západní ideály židovského osvícenství a racionalismu, většinou neznají ani jazyk, jímž se mluví mimo exkluzivní ghetto, „umějí jen židovsky“. Románový text je výrazně symbolický, s romantickými tendencemi, barevný, „maluje slovy“. Těží z žánrového podloží „románové kroniky“, a jakkoliv tímto žánrem de facto není, přesto nás důkladně seznamuje s historií dvou rodů, Todrosů a Ezofovičů. Spisovatelka je dobře obeznámena i s rabínskou interpretací židovství jako služby $\mathrm{v}$ pojetí mystickém. Spaciálnost se projevuje exkluzivitou ghetta jako dominanty představeného areálu: podmínkou inkluzivnosti tohoto prostoru je absolutní podřízení se autoritativní tradici a rituálům, v opačném př́padě tento vylučuje i své židovské spoluvěrce jako „odpadlíky“ (osud Meira Ezofoviče, židovského heretika ${ }^{14}$ ). Exkluzivita prostoru podmiňuje i chování postav, jejich hodnotový svět, jejich myšlení, emocionalitu, očekávání, jazyk a rituály, absolutně odlišné od těch nežidovských, jakkoli i těch nahlížených v kritické perspektivě (spojených s materialismem, oportunismem, naivitou etc.). Jestliže Rakousovy postavy žijí plným životem emancipovaných židů, který bude násilně přerušen až událostmi spojenými s druhou světovou válkou a vyústí v genocidu (holocaust, šoa), většina židovských postav polsko-bělorusko-litevského ghetta v próze Elizy Orzeszkové na svou sociální, jazykovou, intelektuální i náboženskou emancipaci teprve čeká, resp. její potřebu teprve pomalu začíná tušit.

\section{SUMMARY}

In this paper, the author focused on Jewish and Christian topic elements in the cycle of stories named Modche and Rezi (Vojtěch Rakous, 1862 - 1935) and in the novel Meir Ezofowicz (Eliza Orzeszkowa, 1841 - 1910). We discovered two different worlds. The first, represented by Rakous's humoristic stories, is full of idyllic humour and paradoxical glittering, but understanding between the Jews and Christians in a Czech village. The Czech writer and journalist depicted the rural Czech Jews and he created realistic and convincing characters. The language and topics have their roots in the co-existence of Jews with Czechs. The Czech Jews became an inseparable part of our country. His literary work is fully idyllic, but Vojtěch Rakous was a magical storyteller as well, his language is rich and concrete.The second, represented by Orzeszkowa's novel, brings the image of Polish-Belorussian-Lithuanian ghetto named Šibov and shows the exclusive area full of contradictions and antinomies not only between the Jews and Christians, but in particular between two ways of the „divine worship“ and the historical spiritual attendance. Meir Ezofewicz, the proud and meditative young Jew, revolts against ultra-orthodox theory and practice. He struggles for beau-ideal of the ethnical and religious toleration, freedom, for the deeper education of Jewish and gentile, for the cooperation of both, Jewish and non-jewish society.

\section{LITERATÚRA}

Balík, Štěpán, 2015. Jidiš v židovském etnolektu a moderní židovská literární identita v Čechách. Praha: Nakladatelství Lidové noviny.

14 Dovolíme si ještě jednu českou paralelu: Ivan Olbracht v novele O smutných očích Hana Karadžičové portrétuje částečně podobný exkluzivní prostor „pravověrné“ židovské vesnice na Podkarpatské Rusi, přičemž jen přijetí judaismu by dávalo ateistickému ostravskému židu Karadžičovi právo pojmout za ženu vyvolenou Hanele a získat souhlas rodičů - s ženou „odpadlíka“ se ovšem "golet“ loučí, jako kdyby umřela, vlastně jí vystrojí pohřební průvod za živa. 
Čapková, Kateřina, 2005. Češi, Němci, Židé? Národní identita Židů v Čechách, 1918-1938. Praha: Paseka.

Donath, Oskar, 1930. Židé a židovství v české literatuře 19. a 20. století. Díl II. Od Jar. Vrchlického do doby prrítomné. Brno: nákladem vlastním.

Krejčí, Karel, 1953. Dějiny polské literatury. Praha: Československý spisovatel, 369 - 377.

Krejčová, Helena, 2000. Vojtěch Rakous. In: Pavlát, Leo (ed.): Českožidovští spisovatelé v literatuře 20. století. Praha: Židovské muzeum v Praze, 10 - 25.

Kieval, Hillel J., 2011. Formování českého židovstva: národnostní konflikt a židovská společnost $v$ Čechách 1870-1918. Praha: Paseka.

Krzyżanowski, Julian, 1953. Historia małego miasteczka. In: Orzeszkowa, Eliza: Meir Ezofowicz. Warszawa, Czytelnik.

Mikulášek, Alexej, 2000. Antisemitismus v české literatuře 19. a 20. století: teoretická a historická studie. Praha: Votobia.

Mikulášek, Alexej, 2018. Židovská tematika v česko-židovské perspektivě: cyklus povídek „Modche a Rezi“. In: Mezinárodní Masarykova konference pro doktorandy a mladé védecké pracovníky, roč. IX. Hradec Králové: Magnanimitas, 916 - 928.

Mikulášek, Alexej - Glosíková, Viera - Schulz, Antonín B., 1998. Literatura s hvězdou Davidovou: slovníková př́ručka $k$ dějinám česko-židovských a česko-židovsko-německých literárních vztahů 19. a 20. století. Praha: Votobia.

Orzeszková, Eliza, 1953. Meir Ezofovič. Přeložil František Hřivna. Praha: Mladá fronta.

Schmitz, Walter; Udolph, Ludger (eds.), 2001. Tripolis Praga. Die Prager Moderne um 1900. Dresden: Thelem-Universitäts-Verlag.

Sláma, Petr, 2010. Tanu rabanan: antologie rabinské literatury. Praha: Vyšehrad.

The Jews of Czechoslovakia. Historical Studies and Surveys. Volume One. Philadelphia: Jewish Publication Society of America, 1968.

Zawodziński, Wiktor K., 1947. Stulecie trójcy powieściopisarzy: Studia nad społecznym i artystycznym znaczeniem dzieła Orzeszkowej, Prusa, Sienkiewicza. Łódź-Wrocław: W. Bąk.

\section{INTERNETOVÉ ZDROJE}

Krejčová, Helena - Rakous, Vojtěch. In: The Yivo Encyclopedia of Jews in Eastern Europe. Yivo Institute for Jewish, 2010. http://www.yivoencyclopedia.org/article.aspx/Rakous_Vojtech.

Panas, Władysław. 1996. Pismo i rana: Szkice o problematyce żydowskiej w literaturze polskiej. Lublin, Dabar. http://www.biblioteka.teatrnn.pl/dlibra/Content/9258/Pismo_i_rana_szkice.pdf.

\section{KONTAKT}

PhDr. et PaedDr. Alexej Mikulášek

Univerzita Konštantína Filozofa v Nitre

Fakulta stredoeurópskych štúdií

Dražovská 4

94974 Nitra

Slovenská republika

alexej.mikulasek@seznam.cz 